\title{
Effects of autohydrolysis of Eucalyptus urograndis and Eucalyptus grandis on influence of chemical components and crystallinity index
}

\author{
Alaine Patrícia da Silva Morais ${ }^{\mathrm{a}, *}$, Cláudio Angeli Sansígolo ${ }^{\mathrm{a}}$, Mario de Oliveira Neto ${ }^{\mathrm{b}}$ \\ a Laboratório de Celulose e Papel, Departamento de Ciência Florestal, Faculdade de Ciências Agronômicas/UNESP, Faz Experimental Lageado, José Barbosa de Barros, 1780, CEP: \\ 18610-307 Botucatu, SP, Brazil \\ ${ }^{\mathrm{b}}$ Departamento de Física e Biofísica, Instituto de Biociências/UNESP, Distrito de Rubião Júnior, S/N, CEP: 18618-970 Botucatu, SP, Brazil
}

\section{H I G H L I G H T S}

- Sawdust of Brazilian species were autohydrolyzed.

- Hardwoods were subjected to autohydrolysis using various temperatures.

- Chemical compositions of autohydrolyzed sawdust were determined in the solid phase.

- Crystallinity index of autohydrolyzed sawdust was determined.

\section{A R T I C L E I N F O}

\section{Article history:}

Received 7 January 2016

Received in revised form 25 April 2016

Accepted 27 April 2016

Available online 29 April 2016

\section{Keywords:}

Eucalyptus urograndis

Eucalyptus grandis

Autohydrolysis

Chemical components

Crystallinity

\begin{abstract}
A B S T R A C T
Samples of Eucalyptus urograndis and Eucalyptus grandis sawdust were autohydrolyzed in aqueous conditions to reach temperatures in the range $110-190{ }^{\circ} \mathrm{C}$ and reaction times of $0-150 \mathrm{~min}$ in a minireactor. In each minireactor were used a liquor:wood ratio (10:1 L:kg dry wood), in order to assess the effects of the autohydrolysis severity and the crystalline properties of cellulose. The content of extractives, lignin, holocellulose, cellulose, hemicelluloses and crystallinity index obtained from the solid fraction after autohydrolysis of sawdust were determined. This study demonstrated that the hemicelluloses were extensively removed at 170 and $190{ }^{\circ} \mathrm{C}$, whereas cellulose was partly degraded to Eucalyptus urograndis and Eucalyptus grandis sawdust. The lignin content decreased, while the extractives content increased. It was defined that during autohydrolysis, had a slight decreased on crystalline structure of cellulose of Eucalyptus urogandis and Eucalyptus grandis.
\end{abstract}

(c) 2016 Elsevier Ltd. All rights reserved.

\section{Introduction}

The Brazil stands out with the two main sources of wood used for the production of pulp and paper which are eucalyptus and pine forests, accounted for over $98 \%$ of the produced volume. In this way worldwide, the Brazil occupies important positions, it is the fourth largest producer of pulp and the largest producer of eucalyptus pulp. In relation to the paper, Brazil is the ninth largest producer (Bracelpa, 2015).

The pulp industry have focused on studies to isolate the wood components, cellulose, hemicelluloses, lignin and extractives, conceived as integrated facilities enabling the production of a wide

\footnotetext{
* Corresponding author.

E-mail addresses: alainepatriciamorais@yahoo.com.br (A.P. da Silva Morais) sansigolo@fca.unesp.br (C.A. Sansígolo), mario.neto@ibb.unesp.br (M. de Oliveira Neto).
}

spectrum of chemicals and biofuels from biomass (Chirat et al., 2012; Poletto et al., 2012; Sjöström, 1993; Vila et al., 2011).

Cellulose is a long-chain linear polymer composed of $\beta$-D-glucose units which are linked together by $\beta$ - $(1,4)$ glycosidic linkages and the repeating unit of cellulose chain is a cellobiose unit. The cellulose has a strong tendency to form hydrogen bonds (intramolecular and intermolecular). Bundles of cellulose molecules forms the microfibrilis, in which highly ordered (crystalline) regions alternate with less ordered (amorphous) regions. These properties of cellulose have been characterized by X-ray diffraction analysis (D’Almeida, 1988; Fengel and Wegener, 1989; Sjöström, 1993). The crystallinity index was found in some studies: cotton - $73 \%$, mercerized cotton $-51 \%$, pulp wood $-60 \%$ and regenerated cotton - 35\% (Eklund and Lindstrom, 1991; Gümüskaya et al., 2003).

On the other hand, the hemicelluloses differ from cellulose by containing various sugar units, with shorter chains, and by branching of the chain molecules. Monosaccharides that are found at 
hemicelluloses can be subdivided into groups as: pentoses ( $\beta$-Dxylose, $\alpha$-L-arabinose, $\alpha$-L-arabinofuranose), hexoses ( $\beta$-D-glucose, $\beta$-D-mannose, $\alpha$-D-galactose), hexuronic acids ( $\beta$-D-glucuronic acid, $\alpha$-D-4-0-methylglucuronic acid, $\alpha$-D-galacturonic acid) and deoxyhexoses ( $\alpha$-L-rhamnose, $\alpha$-L-fucose). Lignins are polymers of phenylpropane units and the most abundant natural aromatic polymer. An important characteristic of this natural polymer is the presence of different functional groups such as phenolics, methoxyls, aliphatic alcohols, aldehydes, ketones, and ethers. The primary precursors and building units of lignins are: p-coumaryl alcohol, coniferyl alcohol, and sinapyl alcohol. Ultimately, the wood extractives cover a different variety of compounds which can be extracted from wood by solvents (polar and non-polar). The extractives are those compounds which are soluble in organic solvents, and in this sense the term extractives is used in wood analysis. However, water soluble carbohydrates and inorganic compounds (contained in the ash) also belong to the extractable substances (D'Almeida, 1988; Fengel and Wegener, 1989; Sjöström, 1993).

Autohydrolysis consists in an acidic hydrolysis without addition of any external acid. Acetic acid released from the wood when heated in water serves as the acid source (Chirat et al., 2012). When performed under suitable conditions, autohydrolysis leads to xylan breakdown (yielding soluble saccharides), whereas the remaining solid can still be suitable for pulping (Vila et al., 2011). During treatment with acid (sulfuric and oxalic), the glucose dissolves more readily with a steeper slope than during acetic acid treatment and autohydrolysis. Therefore, using autohydrolysis as a pretreatment step will be to effective to pulp yield after cooking (Gütsch et al., 2012). Table 1 shows that the autohydrolysis has been frequently tested with different methods and using a variety of raw materials.

In recent years, studies on the autohydrolysis have been focused the effects on the degradation of the main sugars in Betula pendula wood during hot water extraction (Borrega et al., 2011); the potential of hot water extractions of birch wood to produce highly purified dissolving pulp in a subsequent soda-anthraquinone pulping process (Borrega et al., 2013); the Leucaena leucocephala was subjected to a two-stage fractionation process to obtain a valorized liquid effluent and solid phase (Feria et al., 2012); to evaluate the influence of water autohydrolysis and acid-catalyzed hydrolysis of Eucalyptus globulus wood chips with reference to their potential of providing a substrate for xylan-derived products (Gütsch et al., 2012); the wood hemicelluloses extraction through the autohydrolysis prior to poplar chemi-thermomechanical pulping, including on the characteristics of the autohydrolysis liquor and hydrolyzed chips (Hou et al., 2014) and to compare the effect of steam explosion and steam treatment on the subsequent kraft pulping of Eucalyptus globulus (Martin-Sampedro et al., 2014).

Autohydrolysis of hardwood chips has been investigated to study the kinetics of hemicelluloses degradation and the effects on cellulose and lignin (Garrote et al., 1999; Garrote and Parajó, 2002). It was described that the pre-hydrolysis improved of subsequent kraft pulping method in reason of the increase in the porosity of the wood chips as a result of hemicelluloses and lignin removal in the pre-hydrolysis phase (Liu et al., 2009, 2011).

In the work of Song et al. (2008) the particle size of the raw material varies from industrial size chips to fine wood meal. Because of mass and heat transfer restrictions, the larger the particle size, the lower is the manufacture of extracted products. Based on the above ideas and in the work of Song et al. (2008), we propose a determination the effects of autohydrolysis of the reaction of chemical components and the crystalline properties of cellulose from Brazilian species sawdust (Eucalyptus urograndis and Eucalyptus grandis) using only the solid residue autohydrolyzed wood sawdust to determination.

\section{Materials and methods}

\subsection{Raw material}

The experiments were conducted using ten trees of a clone of a hybrid of Eucalyptus grandis x Eucalyptus urophylla (Eucalyptus urograndis) and ten trees of a clone of Eucalyptus grandis, with six years of age at the time of the cut, gently donated by Lwarcel Celulose in Lençóis Paulista, São Paulo State.

Wood chips from Eucalyptus urograndis and Eucalyptus grandis were reduced to toothpick and after were milled in a Wiley mill to an $40 / 60$ mesh $(0.420 / 0.250 \mathrm{~mm})$ fraction. The resulting samples were air-dried, homogenized in a single lot to avoid differences in composition among aliquots, and was stored in plastic bags for experimental use. The dry matter content of the sawdust were determined according to standard TAPPI for chemical analysis (TAPPI T $264 \mathrm{~cm}-97$ ) for both hardwoods.

\subsection{Autohydrolysis of Eucalyptus urograndis and Eucalyptus grandis sawdust}

Autohydrolysis extractions were conducted in a stainless steel pressure minireactor of $200 \mathrm{~mL}$ volume, equipped with temperature control and mechanical stirring. The sawdust samples

Table 1

Operational conditions used in autohydrolysis process.

\begin{tabular}{|c|c|c|c|}
\hline Raw material & Size & Ratio & Temperature $\left({ }^{\circ} \mathrm{C}\right)$ \\
\hline Betula pendula ${ }^{\mathrm{a}}$ & Coarse sawdust & $\mathrm{L} / \mathrm{W} 40 / 1 \mathrm{~g} / \mathrm{g}$ & $180,200,220,240$ \\
\hline $\operatorname{Birch}^{\mathrm{b}}$ & Chips & $\mathrm{L} / \mathrm{W} 3 / 1 \mathrm{~g} / \mathrm{g}$ & $180,200,220$ \\
\hline Miscanthus $x$ Giganteus ${ }^{c}$ & $1-3 \mathrm{~mm}$ & $\mathrm{~W} / \mathrm{L} 1 / 9 \mathrm{~g} / \mathrm{L}$ & $130,140,150$ \\
\hline Leucaena leucocephala ${ }^{\mathrm{d}}$ & 2 and $10 \mathrm{~mm}$ & $\mathrm{~L} / \mathrm{W} 8 \mathrm{~g} / \mathrm{g}$ & 178 \\
\hline Eucalyptus globulus ${ }^{\mathrm{e}}$ & $2.5-3.5 \mathrm{~mm}$ & $\mathrm{~L} / \mathrm{W} 5 / 1 \mathrm{~mL} / \mathrm{g}$ & $150,170,200$ \\
\hline Poplar $^{\mathrm{f}}$ & Chips & $\mathrm{L} / \mathrm{W} 4 / 1 \mathrm{~kg} / \mathrm{kg}$ & $120,140,150,160$ \\
\hline Eucalyptus globulus ${ }^{g}$ & $8 \mathrm{~mm}$ & $\mathrm{~L} / \mathrm{W} 8 \mathrm{~kg} / \mathrm{kg}$ & $185,190,195,200,205$ \\
\hline Wheat straw ${ }^{\mathrm{h}}$ & $1-2 \mathrm{~cm}$ & $\mathrm{~L} / \mathrm{W} 20 / 1 \mathrm{~mL} / \mathrm{g}$ & $160,180,200,240$ \\
\hline
\end{tabular}

\footnotetext{
a Borrega et al. (2011).

b Borrega et al. (2013).

c El Hage et al. (2010).

d Feria et al. (2012).

e Gütsch et al. (2012).

f Hou et al. (2014).

g Romaní et al. (2011).

h Sidiras et al. (2011).
} 
Table 2

Conditions of the autohydrolysis experiments of Eucalyptus urograndis and Eucalyptus grandis sawdust.

\begin{tabular}{|c|c|c|c|c|c|c|c|}
\hline \multicolumn{8}{|l|}{ Autohydrolysis } \\
\hline Dry sawdust (g) & \multicolumn{7}{|c|}{10} \\
\hline Cooking liquor & \multicolumn{7}{|c|}{$\mathrm{H}_{2} \mathrm{O}$} \\
\hline Liquor:sawdust (L:kg) & \multicolumn{7}{|c|}{$10: 1$} \\
\hline Temperature of reaction $\left({ }^{\circ} \mathrm{C}\right)$ & & 110 & 130 & 150 & 170 & 190 & \\
\hline Time at temperature $(\mathrm{min})^{*}$ & 0 & 5 & 15 & 30 & 60 & 120 & 150 \\
\hline \multicolumn{8}{|c|}{$\begin{array}{l}\text { Conditions for determining the crystallinity index of Eucalyptus urograndis and } \\
\text { Eucalyptus grandis sawdust }\end{array}$} \\
\hline Temperature of reaction $\left({ }^{\circ} \mathrm{C}\right)$ & & 110 & 130 & 150 & 170 & 190 & \\
\hline Time at temperature $(\mathrm{min})^{*}$ & & & 30 & and & 150 & & \\
\hline
\end{tabular}

${ }^{*}$ Heating time used at each extraction temperature.

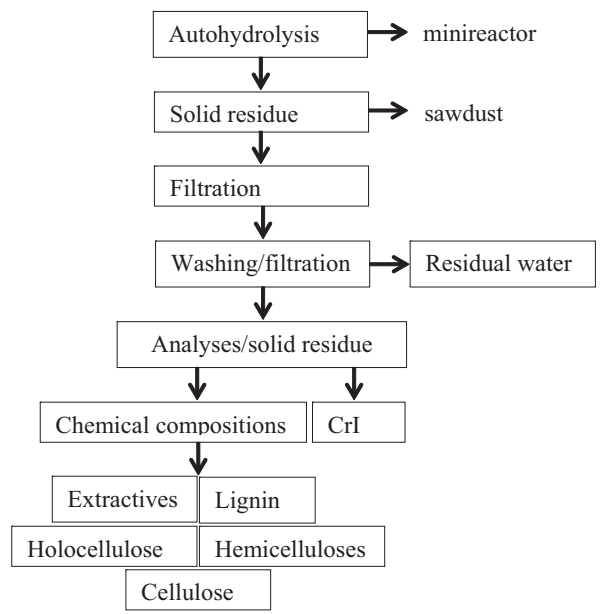

Fig. 1. Experimental flow chart of the autohydrolysis.

(Eucalyptus urograndis and Eucalyptus grandis) 40/60 mesh fraction were placed in the reactor along with $100 \mathrm{~mL}$ of deionized water, reaching a $\mathrm{L}: \mathrm{W}$ ratio of $10: 1 \mathrm{~L}: \mathrm{kg}$ (dry sawdust).

After thermal heating, the reactors were removed from thermal silicone bath and cooled in cold water. The sawdust residue was recovered after filtering in a Büchner funnel. The solid residue was washed with distilled water $(1000 \mathrm{~mL})$, air-dried and stored for analysis. Table 2 shows the conditions of the autohydrolysis experiments of the sawdust samples and the experimental flow diagram of the autohydrolysis is illustrated in Fig. 1.

\subsection{Chemical analysis}

The chemical analysis the sawdust (40/60 mesh) were assayed for total extractives - extracted via Soxhlet: toluene-alcohol, ethyl alcohol and hot water (TAPPI T $204 \mathrm{~cm}-97$ standard); insoluble lignin in sulfuric acid content (TAPPI T 222 om-98 standard); holocellulose content - using sodium chloride delignification (Technical association of the pulp and paper industry - TAPPI, 1999); cellulose content - peracetic method (Wright and Wallis, 1998); the hemicelluloses content - was determined by difference (holocellulose content - cellulose content) for both Eucalyptus urograndis and Eucalyptus grandis hardwoods. The chemical composition of the sawdust with and without autohydrolysis (expressed in $\mathrm{g} / 100 \mathrm{~g}$ wood, oven-dry basis).

\subsection{X-ray diffraction $(X R D)$}

The degree of crystallinity of Eucalyptus urograndis and of Eucalyptus grandis sawdust cellulose was measured by X-ray diffraction and the approach used was the empirical method proposed by Segal et al. (1959), Park et al. (2010) and Poletto et al.
(2012). X-ray diffractograms were collected using a Rigaku diffractometer, with monochromatic $\mathrm{Cu}-\mathrm{K} \alpha$ radiation and wave-length ( $1.542 \AA)$, the generator operating at $40 \mathrm{kV}$ and $40 \mathrm{~mA}$.

The diffraction spectra were taken using the $\theta-2 \theta$ method. Samples were scanned over the range of $2 \theta=0-80^{\circ}$ at a rate of $2{ }^{\circ} \mathrm{C} / \mathrm{min}^{-1}$. The definition of the crystallinity index ( $\left.\mathrm{CrI}\right)$ in which $I_{(002)}$ is the intensity of the crystalline peak at about $2 \theta \approx 22-23^{\circ}$, attributed to crystalline regions and $I_{(\mathrm{AM})}$ is the intensity at $2 \theta \approx 18^{\circ}$, attributed to amorphous regions (Segal et al., 1959; Park et al., 2010; Poletto et al., 2012).

CrI was calculated from the ratio of the height of the maximum peak $\left(I_{002}\right)$ and the height of the minimum peak $\left(I_{\mathrm{AM}}\right)$, i.e., $\mathrm{CrI}$ was calculated from the height ratio between the intensity of the crystalline peak $\left(I_{002}-I_{\mathrm{AM}}\right)$ and total intensity $\left(I_{002}\right)$ after subtraction of the background signal measured without cellulose. Crystallinity index was calculated using the Eq. (1) defined by Segal et al. (1959), Park et al. (2010) and Poletto et al. (2012).

$I_{\mathrm{Cr}}=\frac{I_{(002)}-I_{(\mathrm{AM})}}{I_{(002)}} \times 100$

Table 2 shows the experimental parameters studied to the $\mathrm{CrI}$ analysis of the sawdust samples.

\section{Results and discussion}

3.1. Chemical composition of Eucalyptus urograndis and Eucalyptus grandis in natura sawdust (without autohydrolysis)

The results for the chemical composition of the wood species studied are presented in Table 3. All percentages were determined relative to absolutely dry (o.d.) sawdust and the analysis of chemical composition of sawdust (holocellulose, cellulose, hemicelluloses and lignin) were made of extractives-free.

\subsection{Chemical composition of the autohydrolyzed sawdust}

\subsubsection{Extractives content}

The contents of extractive at temperatures of 110, 130 and $150{ }^{\circ} \mathrm{C}$ compared with in natura was slightly altered after the autohydrolysis of Eucalyptus urograndis and Eucalyptus grandis sawdust (Tables 4 and 5). As can be seen (Tables 4 and 5) an increasing autohydrolysis temperature of 170 and $190^{\circ} \mathrm{C}$ led to a significant increased of content of extractives reached maximum value of $7.77 \%$ (Table 4 ) and $7.07 \%$ (Table 5) for content of extractives of sawdusts.

Due to the severe extraction conditions used it can be observed that there was an increase in the extractives content of in the both sawdusts after autohydrolysis. The explanation could be by the reason that during the autohydrolysis some macromolecules are partially degraded becoming extractible in a subsequent solvent extraction (Martin-Sampedro et al., 2011, 2014; Rahikainen et al., 2013). However, a decrease extractives content after $150 \mathrm{~min}$ it is $4.27 \%$ (Table 5), the reason could be the partial degradation of

Table 3

Chemical composition of Eucalyptus urograndis and Eucalyptus grandis sawdust (in natura - without autohydrolysis).

\begin{tabular}{lcc}
\hline Component & Eucalyptus urograndis & Eucalyptus grandis \\
\hline Total extractives & 1.81 & 2.91 \\
Insoluble lignin & 23.24 & 21.94 \\
Holocellulose & 86.25 & 80.83 \\
Cellulose & 42.83 & 40.85 \\
Hemicelluloses & 43.42 & 39.98
\end{tabular}

Dry basis (\%).

By difference (holocellulose - cellulose). 
Table 4

Chemical compositions of the sawdust autohydrolyzed from Eucalyptus urograndis.

\begin{tabular}{|c|c|c|c|c|c|c|}
\hline \multicolumn{2}{|c|}{ Chemical composition (\%) } & \multirow[t]{2}{*}{ Extractives } & \multirow[t]{2}{*}{ Lignin } & \multirow[t]{2}{*}{ Holocellulose } & \multirow[t]{2}{*}{ Cellulose } & \multirow[t]{2}{*}{ Hemicelluloses } \\
\hline Temperature & Time (min) & & & & & \\
\hline \multirow[t]{6}{*}{$110\left({ }^{\circ} \mathrm{C}\right)$} & 5 & 4.05 & 22.22 & 79.34 & 39.53 & 39.80 \\
\hline & 15 & 2.90 & 22.63 & 80.06 & 41.18 & 38.88 \\
\hline & 30 & 3.15 & 23.59 & 80.18 & 41.62 & 38.56 \\
\hline & 60 & 2.26 & 22.64 & 76.45 & 43.57 & 32.88 \\
\hline & 120 & 2.29 & 22.72 & 77.18 & 43.53 & 33.65 \\
\hline & 150 & 2.65 & 23.89 & 80.30 & 43.05 & 37.25 \\
\hline \multirow[t]{6}{*}{$130\left({ }^{\circ} \mathrm{C}\right)$} & 5 & 3.40 & 21.81 & 79.69 & 43.83 & 35.86 \\
\hline & 15 & 2.60 & 22.66 & 79.56 & 43.52 & 36.04 \\
\hline & 30 & 2.49 & 22.60 & 77.01 & 42.60 & 34.41 \\
\hline & 60 & 2.87 & 22.24 & 77.04 & 42.35 & 34.68 \\
\hline & 120 & 2.46 & 21.10 & 76.12 & 42.65 & 33.47 \\
\hline & 150 & 2.86 & 22.17 & 75.98 & 42.04 & 33.93 \\
\hline \multirow[t]{6}{*}{$150\left({ }^{\circ} \mathrm{C}\right)$} & 5 & 2.24 & 25.19 & 78.80 & 42.73 & 36.08 \\
\hline & 15 & 1.77 & 24.21 & 79.59 & 42.53 & 37.05 \\
\hline & 30 & 2.43 & 24.88 & 78.60 & 42.14 & 36.06 \\
\hline & 60 & 2.21 & 25.13 & 75.61 & 42.42 & 33.20 \\
\hline & 120 & 2.27 & 24.00 & 71.23 & 41.21 & 30.02 \\
\hline & 150 & 3.42 & 23.50 & 68.16 & 42.29 & 25.87 \\
\hline \multirow[t]{6}{*}{$170\left({ }^{\circ} \mathrm{C}\right)$} & 5 & 0.78 & 21.80 & 77.78 & 40.33 & 37.45 \\
\hline & 15 & 1.52 & 21.16 & 78.78 & 43.36 & 35.42 \\
\hline & 30 & 1.74 & 21.94 & 73.07 & 42.23 & 30.84 \\
\hline & 60 & 3.81 & 20.13 & 60.47 & 41.86 & 18.61 \\
\hline & 120 & 6.22 & 18.56 & 52.16 & 39.35 & 12.81 \\
\hline & 150 & 4.54 & 19.64 & 53.85 & 35.78 & 18.07 \\
\hline \multirow[t]{6}{*}{$190\left({ }^{\circ} \mathrm{C}\right)$} & 5 & 1.42 & 22.27 & 81.57 & 41.58 & 39.99 \\
\hline & 15 & 1.65 & 23.22 & 82.29 & 44.10 & 38.19 \\
\hline & 30 & 3.09 & 20.99 & 68.41 & 42.74 & 25.67 \\
\hline & 60 & 6.04 & 18.79 & 52.48 & 37.50 & 14.98 \\
\hline & 120 & 7.16 & 17.52 & 50.96 & 39.38 & 11.58 \\
\hline & 150 & 7.77 & 17.53 & 50.47 & 37.56 & 12.91 \\
\hline
\end{tabular}

Dry basis (\%).

Table 5

Chemical compositions of the sawdust autohydrolyzed from Eucalyptus grandis.

\begin{tabular}{|c|c|c|c|c|c|c|}
\hline \multicolumn{2}{|c|}{ Chemical composition (\%) } & \multirow[t]{2}{*}{ Extractives } & \multirow[t]{2}{*}{ Lignin } & \multirow[t]{2}{*}{ Holocellulose } & \multirow[t]{2}{*}{ Cellulose } & \multirow[t]{2}{*}{ Hemicelluloses } \\
\hline Temperature & Time (min) & & & & & \\
\hline \multirow[t]{6}{*}{$110\left({ }^{\circ} \mathrm{C}\right)$} & 5 & 3.12 & 22.56 & 77.91 & 40.82 & 37.09 \\
\hline & 15 & 2.65 & 25.31 & 79.21 & 39.26 & 39.65 \\
\hline & 30 & 2.98 & 20.06 & 79.77 & 41.82 & 37.95 \\
\hline & 60 & 2.95 & 19.87 & 78.24 & 41.09 & 37.15 \\
\hline & 120 & 3.30 & 19.02 & 78.27 & 40.41 & 37.86 \\
\hline & 150 & 2.43 & 18.95 & 77.53 & 42.45 & 35.09 \\
\hline \multirow[t]{6}{*}{$130\left({ }^{\circ} \mathrm{C}\right)$} & 5 & 3.10 & 23.70 & 78.31 & 41.08 & 37.23 \\
\hline & 15 & 2.70 & 21.88 & 79.08 & 42.52 & 36.56 \\
\hline & 30 & 2.56 & 22.49 & 78.34 & 40.51 & 37.83 \\
\hline & 60 & 2.10 & 21.58 & 77.75 & 42.88 & 34.87 \\
\hline & 120 & 2.04 & 23.68 & 76.81 & 42.46 & 34.35 \\
\hline & 150 & 1.72 & 20.49 & 78.14 & 41.95 & 36.19 \\
\hline \multirow[t]{6}{*}{$150\left({ }^{\circ} \mathrm{C}\right)$} & 5 & 1.82 & 23.31 & 79.72 & 42.77 & 36.94 \\
\hline & 15 & 2.57 & 21.80 & 79.77 & 42.97 & 36.81 \\
\hline & 30 & 1.75 & 22.64 & 78.64 & 39.87 & 38.76 \\
\hline & 60 & 2.25 & 21.64 & 77.57 & 40.23 & 37.34 \\
\hline & 120 & 3.57 & 22.87 & 71.63 & 40.31 & 31.33 \\
\hline & 150 & 3.92 & 21.62 & 68.58 & 38.54 & 30.04 \\
\hline \multirow[t]{6}{*}{$170\left({ }^{\circ} \mathrm{C}\right)$} & 5 & 1.42 & 19.53 & 79.25 & 42.10 & 37.14 \\
\hline & 15 & 1.55 & 22.64 & 78.24 & 41.16 & 37.08 \\
\hline & 30 & 2.50 & 20.78 & 73.34 & 41.22 & 32.12 \\
\hline & 60 & 3.96 & 21.66 & 72.58 & 43.00 & 29.58 \\
\hline & 120 & 5.72 & 19.40 & 52.32 & 39.54 & 12.78 \\
\hline & 150 & 5.92 & 18.41 & 51.20 & 39,12 & 12.07 \\
\hline \multirow[t]{6}{*}{$190\left({ }^{\circ} \mathrm{C}\right)$} & 5 & 1.71 & 20.12 & 78.70 & 42.94 & 35.76 \\
\hline & 15 & 1.42 & 22.44 & 78.48 & 43.03 & 35.45 \\
\hline & 30 & 3.49 & 19.34 & 61.56 & 40.87 & 20.69 \\
\hline & 60 & 6.90 & 18.33 & 50.91 & 41.28 & 9.63 \\
\hline & 120 & 7.07 & 17.23 & 48.95 & 37.65 & 11.30 \\
\hline & 150 & 4.27 & 19.44 & 53.34 & 38.86 & 14.48 \\
\hline
\end{tabular}

Dry basis (\%). 
polysaccharides mainly hemicellulose (Martin-Sampedro et al., 2014).

\subsubsection{Lignin content}

Lignin was only partially removed during the autohydrolysis (Tables 4 and 5). The lignin content after the autohydrolysis were increased from $0.35 \%$ to $0.65 \%$ (Table 4 ); $0.62 \%$ to $3.37 \%$ (Table 5 ) and was decreased from $0.52 \%$ to $1.02 \%$ (Table 4 ); $1.88 \%$ to $2.99 \%$ (Table 5) all at $110^{\circ} \mathrm{C}$ compared with in natura. However, the lignin content decreased all times at 130,170 and $190{ }^{\circ} \mathrm{C}$ (Table 4), maximum of the $5.72 \%$ in relation of the initial it is $23.24 \%$, only increased at $150{ }^{\circ} \mathrm{C}$ (Table 4) and increased and decreased at 130 and $150{ }^{\circ} \mathrm{C}$ (Table 5). Therefore, lignin shows a different behavior, starting always from a high temperature $\left(170\right.$ and $\left.190{ }^{\circ} \mathrm{C}\right)$ and then rapidly decreasing followed by a lower decreasing rate, with both Eucalyptus urograndis and of Eucalyptus grandis sawdust compared with in natura (Tables 4 and 5).

In this study, in some treatments of autohydrolysis the lignin content decreased compared with in natura of Eucalyptus urograndis and of Eucalyptus grandis sawdust. According to Hou et al. (2014) the chemical compositions of the hydrolyzed poplar chips decreased compared with the original from $22.54 \%$ to $18.71 \%$ at $160{ }^{\circ} \mathrm{C}$ for $60 \mathrm{~min}$ to klason lignin.

There are reasons for explaining the decreased content of lignin: after autohydrolysis lignin is known to be structurally changed and more easily extracted with organic solvents (Gütsch et al., 2012; Hou et al., 2014; Leschinsky et al., 2009; Lora and Wayman, 1980).

\subsubsection{Holocellulose content}

Holocellulose content is expressed as addition of cellulose and hemicelluloses contents.

The holocellulose content decreased from $86.25 \%$ (Table 3) up to values in the range $76.45-80.30 \%$ to Eucalyptus urograndis sawdust (Table 4) and from $80.83 \%$ (Table 3 ) up to values in the range $77.53-79.77 \%$ to Eucalyptus grandis sawdust (Table 5) at $110^{\circ} \mathrm{C}$. At 130 and $150{ }^{\circ} \mathrm{C}$ the holocellulose content decreased up to values in the range $68.16-79.69 \%$ and $68.58-79.77 \%$ to Eucalyptus urograndis and Eucalyptus grandis sawdust, respectively (Tables 4 and 5). Whereas higher severities $\left(170\right.$ and $190{ }^{\circ} \mathrm{C}$ ) resulted in a significantly decreased holocellulose content which reached a minimum values of $50.47 \%$ and $48.95 \%$ to Eucalyptus urograndis and Eucalyptus grandis sawdust, respectively compared with in natura (Tables 4 and 5).

According to Hou et al. (2014), the holocellulose were the main components of the autohydrolyzed poplar wood chips, which was beneficial to chemi-thermomechanical pulp production. And also according to Martin-Sampedro et al. (2014) as expected the main components extracted in both pre-treatments (steam explosion and steam) from Eucalyptus globulus were holocellulose.

\subsubsection{Hemicelluloses content}

The percentage of hemicelluloses content decreased at 110,130, 150,170 and $190^{\circ} \mathrm{C}$ (Tables 4 and 5) compared with in natura (Table 3). Under the present extraction conditions, hemicelluloses was nearly-quantitatively removed at 170 and $190^{\circ} \mathrm{C}$ (Tables 4 and 5).

When temperature was raised to $170^{\circ} \mathrm{C}$, corresponding content of hemicelluloses the autohydrolyzed sawdust decreased from $43.42 \%$ (Table 3) to $12.81 \%$ (Table 4 ) and at $190{ }^{\circ} \mathrm{C}$ decreased from $43.42 \%$ to $11.58 \%$ (Table 4 ) to Eucalyptus urograndis. The Eucalyptus grandis sawdust decreased from 39.98\% (Table 3) to $12.07 \%$ at $170{ }^{\circ} \mathrm{C}$ (Table 5), and decreased from $39.98 \%$ to $9.63 \%$ at $190{ }^{\circ} \mathrm{C}$ (Table 5 ).

Indicating that the autohydrolysis had a great effect on hemicelluloses dissolution from the Eucalyptus urograndis and Eucalyptus grandis sawdust.
According to Chirat et al. (2012), a minimum temperature of $140{ }^{\circ} \mathrm{C}$ for the autohydrolysis was necessary to start removing significant quantities of hemicelluloses and at $160{ }^{\circ} \mathrm{C}$, the removal of pentosans was linear with the time of hydrolysis utilizing Eucalyptus globulus wood chips.

However, Tunc and van Heiningen (2008), showed that only a very small amount of cellulose was removed during extraction compared to hemicelluloses, after the autohydrolysis at $150{ }^{\circ} \mathrm{C}$ utilizing a mixture of southern hardwood chips.

\subsubsection{Cellulose content}

The cellulose yield remained rather constant after the autohydrolysis, with only a slight decreased even after high severity extraction (Tables 4 and 5).

The cellulose content of solid residues decreased first from $42.83 \%$ (Table 3) up to $39.53 \%$, and then increased to reach $43.57 \%$ in the experiment performed at $110^{\circ} \mathrm{C}$ (Table 4). At $130{ }^{\circ} \mathrm{C}$ increased (about the 1\%) and decreased (about the 0.79), at $150{ }^{\circ} \mathrm{C}$ only decreased (about the $1.62 \%$ ), at $170{ }^{\circ} \mathrm{C}$ decreased (about the $7.05 \%$ ) and at $190{ }^{\circ} \mathrm{C}$ decreased (about $5.27 \%$ ) to Eucalyptus urograndis sawdust as is shown in Table 4, compared with in natura (Table 3). However, the cellulose content of solid residues to Eucalyptus grandis sawdust decreased (about the $1.59 \%$ ) and increased (about the $1.6 \%$ ) at $110{ }^{\circ} \mathrm{C}$ (Table 5), at $130{ }^{\circ} \mathrm{C}$ increased about the $2.03 \%$ (Table 5), at $150{ }^{\circ} \mathrm{C}$ increased about the $2.02 \%$ and decreased about the $2.31 \%$ (Table 5). On the other hand, Table 5 exhibit that at 170 and $190{ }^{\circ} \mathrm{C}$ increased first (about the 2.18\%) and after decreased (about the 3.2\%) all compared with in natura (Table 3 ).

According to Tunc et al. (2010), when a small amount of the cellulose dissolved, likely were resulting from the degradation of amorphous regions in cellulose.

\subsection{Crystallinity index in Eucalyptus urograndis and Eucalyptus grandis sawdust samples}

The crystallinity index of the raw material are shown in Table 6.

The $\mathrm{CrI}$ in samples between decreased 1.01-8.32\% and between increased $0.53-5.9 \%$ to Eucalyptus urograndis sawdust. On the

\section{Table 6}

Crystallinity index obtained by X-ray diffraction in sawdust autohydrolyzed from Eucalyptus urograndis and Eucalyptus grandis.

\begin{tabular}{|c|c|c|c|c|c|}
\hline Sawdust species & $\begin{array}{l}\text { Temperature } \\
\left({ }^{\circ} \mathrm{C}\right)\end{array}$ & $\begin{array}{l}\text { Time } \\
(\mathrm{min})\end{array}$ & $\begin{array}{l}\text { CrI } \\
(\%)\end{array}$ & $I_{(002)}$ & $I_{(\mathrm{AM})}$ \\
\hline & in natura* & & 62.03 & 0.9394 & 0.2998 \\
\hline \multirow{11}{*}{$\begin{array}{l}\text { Eucalyptus } \\
\text { urograndis }\end{array}$} & 110 & 30 & 53.71 & 0.8501 & 0.2661 \\
\hline & & 150 & 62.19 & 0.9206 & 0.2750 \\
\hline & 130 & 30 & 62.56 & 0.9245 & 0.2763 \\
\hline & & 150 & 61.02 & 0.9199 & 0.2849 \\
\hline & 150 & 30 & 58.40 & 0.8971 & 0.2809 \\
\hline & & 150 & 65.99 & 0.9324 & 0.2541 \\
\hline & 170 & 30 & 62.03 & 0.9138 & 0.2682 \\
\hline & & 150 & 63.76 & 0.8871 & 0.2213 \\
\hline & 190 & 30 & 65.35 & 0.9064 & 0.2292 \\
\hline & & 150 & 71.25 & 0.9214 & 0.1925 \\
\hline & in natura* & & 57.97 & 0.9192 & 0.3121 \\
\hline \multirow[t]{10}{*}{ Eucalyptus grandis } & 110 & 30 & 54.39 & 0.8759 & 0.2908 \\
\hline & & 150 & 56.76 & 0.8854 & 0.2814 \\
\hline & 130 & 30 & 61.51 & 0.9221 & 0.2831 \\
\hline & & 150 & 60.38 & 0.8918 & 0.2568 \\
\hline & 150 & 30 & 59.71 & 0.8955 & 0.2672 \\
\hline & & 150 & 58.59 & 0.8775 & 0.2559 \\
\hline & 170 & 30 & 63.52 & 0.9309 & 0.2753 \\
\hline & & 150 & 61.64 & 0.8695 & 0.2201 \\
\hline & 190 & 30 & 63.82 & 0.9022 & 0.2382 \\
\hline & & 150 & 70.36 & 0.9367 & 0.2183 \\
\hline
\end{tabular}

in natura - without autohydrolysis. 
other hand, the CrI between decreased 1.21-3.58\% and between increased $0.62-6.54 \%$ to Eucalyptus grandis, compared with in natura in both.

However, the CrI can be regarded as an indirect measurement of hemicelluloses removal after from autohydrolysis of Eucalyptus urograndis and of Eucalyptus grandis sawdust, leaving intact the crystalline cellulose fraction in the autohydrolyzed residues (Castro et al., 2013; Inoue et al., 2008).

\section{Conclusions}

With increasing the severity factor $\left(170-190^{\circ} \mathrm{C}\right)$ in the autohydrolysis of the Eucalyptus urograndis and Eucalyptus grandis sawdust, the extractives content increased from 1.81 to $7.77 \%$ and 2.91 to $7.07 \%$ respectively while the lignin content decreased from 23.24 to $17.52 \%$ and 21.94 to $17.93 \%$. The autohydrolysis of sawdust allowed solubilization of hemicelluloses and resulted in $31.84 \%$ (E. urograndis) and $30.35 \%$ (E. grandis) to maximum removal, of the initial sample. Compared with the hemicelluloses were little degradation of cellulose about 7.05\% (E. urograndis) and 3.2\% (E. grandis). However, whereas decreased the hemicelluloses content, were noted an increased in the crystallinity index, about $9.22 \%$ (E. urograndis) and $12.39 \%$ (E. grandis).

\section{Acknowledgements}

The authors gratefully acknowledge by the financial support of the UNESP and are grateful to Faculty of Agronomic Science - FCA/ UNESP, Botucatu-Brazil at the support of this work.

\section{References}

Borrega, M., Nieminen, K., Sixta, H., 2011. Degradation kinetics of the main carbohydrates in birch wood during hot water extraction in a batch reactor at elevated temperatures. Bioresour. Technol. 102, 10724-10732.

Borrega, M., Tolonen, L.K., Bardot, F., Testova, L., Sixta, H., 2013. Potential of hot water extraction of birch wood to produce high-purity dissolving pulp after alkaline pulping. Bioresour. Technol. 135, 665-671.

Bracelpa Brazilian Pulp \& Paper Association, 2015. Sector panorama, Bracelpa, São Paulo. <http://bracelpa.org.br/bra2/sites/default/files/estatisticas/booklet.pdf>.

Castro, J.F., Parra, C., Yáñez-S, M., Rojas, J., Mendonça, R.T., Baeza, J., Freer, J., 2013. Optimal pretreatment of Eucalyptus globulus by hydrothermolysis and alkaline extraction for microbial production of ethanol and xylitol. Ind. Eng. Chem. Res. 52, 5713-5720.

Chirat, C., Lachenal, D., Sanglard, M., 2012. Extraction of xylans from hardwood chips prior to kraft cooking. Process Biochem. 47, 381-385.

D’Almeida, M.L.O. (Coord.), 1988. Pulp and Paper: Manufacturing Technology of Cellulose Pulp, second ed. IPT, São Paulo, Brazil.

Eklund, D., Lindstrom, T., 1991. Paper Chemistry - An introduction. DT Paper Science Publications, Grankulla, Finland.

El Hage, R., Chrusciel, L., Desharnais, L., Brosse, N., 2010. Effect of autohydrolysis of Miscanthus $x$ giganteus on lignin structure and organosolv delignification. Bioresour. Technol. 101, 9321-9329.

Fengel, D., Wegener, G., 1989. Wood: Chemistry, Ultrastructure, Reactions. Walter de Gruyter, Berlin, New York.

Feria, M.J., García, J.C., Díaz, M.J., Fernández, M., López, F., 2012. Biorefinery process for production of paper and oligomers from Leucaena leucocephala $k 360$ with or without prior autohydrolysis. Bioresour. Technol. 126, 64-70.

Garrote, G., Parajó, J.C., 2002. Non isothermal autohydrolysis of Eucalyptus wood. Wood Sci. Technol. 36, 111-123.
Garrote, G., Domínguez, H., Parajó, J.C., 1999. Hydrothermal processing of lignocellulosic materials. Holz Roh Werkst 57, 191-202.

Gümüskaya, E., Usta, M., Kirci, H., 2003. The effects of various pulping conditions on crystalline structure of cellulose in cotton linters. Polym. Degrad. Stab. 81, 559564.

Gütsch, J.S., Nousiainen, T., Sixta, H., 2012. Comparative evaluation of autohydrolysis and acid-catalyzed hydrolysis of Eucalyptus globulus wood. Bioresour. Technol. 109, 77-85.

Hou, Q., Wang, Y., Liu, W., Liu, L., Xu, N., Li, Y., 2014. An application study of autohydrolysis pretreatment prior to poplar chemi-thermomechanical pulping. Bioresour. Technol. 169, 155-161.

Inoue, H., Yano, S., Endo, T., Sakaki, T., Sawayama, S., 2008. Combining hotcompressed water and ball milling pretreatments to improve the efficiency of the enzymatic hydrolysis of eucalyptus. Biotechnol. Biofuels 1 (2), 1-9.

Leschinsky, M., Sixta, H., Patt, R., 2009. Detailed mass balances of the autohydrolysis of Eucalyptus globulus at $170{ }^{\circ} \mathrm{C}$. BioResources 4 (2), 687-703.

Liu, S., Mishra, G., Amidon, T.E., Gratien, K., 2009. Effect of hot-water extraction of woodchips on the kraft pulping of Eucalyptus woodchips. J. Biobased Mater Bioenergy 3 (4), 363-372.

Liu, Z., Fatehi, P., Jahan, M.S., Ni, Y., 2011. Separation of lignocellulosic materials by combined processes of pre-hydrolysis and ethanol extraction. Bioresour. Technol. 102, 1264-1269.

Lora, J.H., Wayman, M., 1980. Autohydrolysis of aspen milled wood lignin. Can. J. Chem. 58, 669-676.

Martin-Sampedro, R., Eugenio, M.E., Revilla, E., Martín, J.A., Villar, J.C., 2011 Integration of kraft pulping on a forest biorefinery by the addition of a steam explosion pretreatment. BioResources 6 (1), 513-528.

Martin-Sampedro, R., Eugenio, M.E., Moreno, J.A., Revilla, E., Villar, J.C., 2014. Integration of a kraft pulping mill into a forest biorefinery: pre-extraction of hemicellulose by steam explosion versus steam treatment. Bioresour. Technol. $153,236-244$.

Park, S., Baker, J.O., Himmel, M.E., Parilla, P.A., Johnson, D., 2010. Cellulose crystallinity index: measurement techniques and their impact on interpreting cellulase performance. Biotechnol. Biofuels 3 (10), 1-10.

Poletto, M., Zattera, A.J., Forte, M.M.C., 2012. Thermal decomposition of wood: Influence of wood components and cellulose crystallite size. Bioresour. Technol. 109, 148-153.

Rahikainen, J.L., Martin-Sampedro, R., Heikkinen, H., Rovio, S., Marjamaa, K., Tamminen, T., Rojas, O.J., Kruus, K., 2013. Inhibitory effect of lignin during cellulose bioconversion: the effect of lignin chemistry on non-productive enzyme adsorption. Bioresour. Technol. 133, 270-278.

Romaní, A., Garrote, G., López, F., Parajó, J.C., 2011. Eucalyptus globulus wood fractionation by autohydrolysis and organosolv delignification. Bioresour. Technol. 102, 5896-5904.

Segal, L., Creely, J.J., Martin Jr., A.E., Conrad, C.M., 1959. An empirical method for estimating the degree of crystallinity of native cellulose using the X-ray diffractometer. Text. Res. J. 29 (10), 786-794.

Sidiras, D., Batzias, F., Ranjan, R., Tsapatis, M., 2011. Simulation and optimization of batch autohydrolysis of wheat straw to monosaccharides and oligosaccharides. Bioresour. Technol. 102, 10486-10492.

Sjöström, E., 1993. Wood Chemistry: Fundamentals and Applications, second ed. San Diego, New York.

Song, T., Pranovich, A., Sumerskiy, I., Holmbom, B., 2008. Extraction of galactoglucomannan from spruce wood with pressurized hot water. Holzforschung 62, 659-666.

Technical association of the pulp and paper industry, TAPPI, 1999. Test methods (compact disc), Atlanta: TAPPI 1998-1999.

Tunc, M.S., van Heiningen, A.R.P., 2008. Hemicellulose extraction of mixed southern hardwood with water at $150^{\circ} \mathrm{C}$ : effect of time. Ind. Eng. Chem. Res. 47, $7031-$ 7037.

Tunc, M.S., Lawoko, M., van Heiningen, A., 2010. Understanding the limitations of removal of hemicelluloses during autohydrolysis of a mixture of southern hardwoods. BioResources 5 (1), 356-371.

Vila, C., Romero, J., Francisco, J.L., Garrote, G., Parajó, J.C., 2011. Extracting value from Eucalyptus wood before kraft pulping: Effects of hemicelluloses solubilization on pulp properties. Bioresour. Technol. 102, 5251-5254.

Wright, P.J., Wallis, A.F.A., 1998. Rapid determination of cellulose in plantation Eucalypt woods to predict kraft pulp yields. Tappi J. 81 (2), 126-130. 